\title{
FIRST RECORD OF THE BERMUDA SEA CHUB, KYPHOSUS SALTATRIX (ACTINOPTERYGII: PERCIFORMES: KYPHOSIDAE), IN THE COASTAL WATERS OF LIBYA
}

\author{
Houssein ELBARAASI ${ }^{1}{ }^{*}$, Osama BOGRARA ${ }^{2}$, Osama ELSILINI ${ }^{1}$, and Jalal BOJWARI ${ }^{1}$ \\ ${ }^{1}$ Department of Zoology, Faculty of Science, Benghazi University, Benghazi, Libya \\ ${ }^{2}$ Marine World Fisheries Ltd., Jeliana Ave., Benghazi, Libya
}

Elbaraasi H., Bograra O., Elsilini O., Bojwari J. 2013. First record of the Bermuda sea chub, Kyphosus saltatrix (Actinopterygii: Perciformes: Kyphosidae), in the coastal waters of Libya. Acta Ichthyol. Piscat. 43 (3): 251-253.

\begin{abstract}
In this paper, we report the first record of Bermuda sea chub, Kyphosus saltatrix (Linnaeus, 1758) caught off the coast of Benghazi, Libya. Its occurrence adds to the increasing rate of detections of this species in the south of the Mediterranean during the last decade.
\end{abstract}

Keywords: Kyphosus saltatrix, Benghazi, Libyan coast, Occurrence, Mediterranean

The family Kyphosidae is composed of approximately 45 species, all of which inhabit mainly the Atlantic-, Indian, and Pacific Oceans (Nelson 2006, Froese and Pauly 2013).

Bermuda sea chub, Kyphosus saltatrix (Linnaeus, 1758), is a relatively common species in the western Atlantic, ranging from Massachusetts (USA) southward throughout the Gulf of Mexico and the Caribbean, down to south-eastern Brazil (Sgano 1978, Wheeler 1985). However, it seems a fairly rare species in the north-eastern Atlantic, although present along the west coast of Africa, from Morocco with sporadic occurrences to at least the Gulf of Guinea and the coast of Angola (Sgano 1981, Tortonese 1986, Desoutter 1990). This species is rarely found in the Mediterranean, with only few occurrences reported: three records off the Ligurian-, Tyrrhenian-, and Adriatic coasts of Italy (Desoutter 1973, Tortonese 1986) and another record off Mallorca Island, western Mediterranean (Merella et al. 1998), off Saint Tropez, south east France (Francour and Mouine 2008). The most recent record was given from the Ionian Sea (western Greece) based on a single specimen caught during 2011 (Kiparissis et al. 2012). In North Africa, some specimens were recorded as wellin Algeria (Hemida et al. 2004) and in Tunisia (Hattour 2006, Lelong 2012).

The Bermuda sea chub Kyphosus saltatrix inhabits shallow waters ranging from 1 to $30 \mathrm{~m}$ depth, over turtle grass, sandy or rocky bottoms, and around coral reefs (Sgano 1978, Wheeler 1985, Tortonese 1986, Carpenter 2002) and sometimes offshore in deeper waters (Wheeler 1985). The young are commonly found below or among floating Sargassum weeds (Sgano 1978, Wheeler 1985, Tortonese 1986). They are often called rudderfish because they associate with floating objects (namely driftwood) and also following ships (Wheeler 1985, Carpenter 2002). It feeds primarily on benthic macroalgae, but also takes small crustaceans and molluscs associated with the algae (Sgano 1981, Wheeler 1985, Tortonese 1986, Carpenter 2002).

The presently described specimen of Kyphosus saltatrix (Fig. 1) was caught on 15 November 2010 off the coast of Benghazi, Libya (southern Mediterranean), by spearfishing at approximately $7 \mathrm{~m}$ depth, close to the sea Port of Benghazi $\left(32^{\circ} 06^{\prime} \mathrm{N}, 20^{\circ} 03^{\prime} \mathrm{E}\right)$. Water temperature at the day of capture was $18^{\circ} \mathrm{C}$. The fish was frozen by the fisherman. Once in the laboratory, the specimen was photographed, identified, and has been deposited in the Natural Museum of the Zoology Department, Faculty of Science, Benghazi University, Benghazi, Libya. The main morphometric (Table 1) and meristic (Table 2) data are shown in, which are in agreement with data reported by other authors who described K. saltatrix (see Sgano 1978, 1981, Tortonese 1986, Carpenter 2002, Canas et al. 2005, Nelson 2006, Froese and Pauly 2013). The specimen was a female with $47.5 \mathrm{~cm}$ total length (TL) and it weighed $1630 \mathrm{~g}$. It is oval in shape with a small mouth full of incisiform, hockeystick shaped teeth.

The capture of this specimen of Bermuda sea chub off the Benghazi coast is the first record in Libyan waters and the fourth finding reported from the North-African coast (southern Mediterranean), which confirms the spread of this species along the North-African coast (Lelong 2012). This occurrence could mainly be attributed to the global phenomenon of seawater warming that allows species of tropical and subtropical origin to enter and establish in the Mediterranean Sea (Golani et al. 2002). Furthermore, 


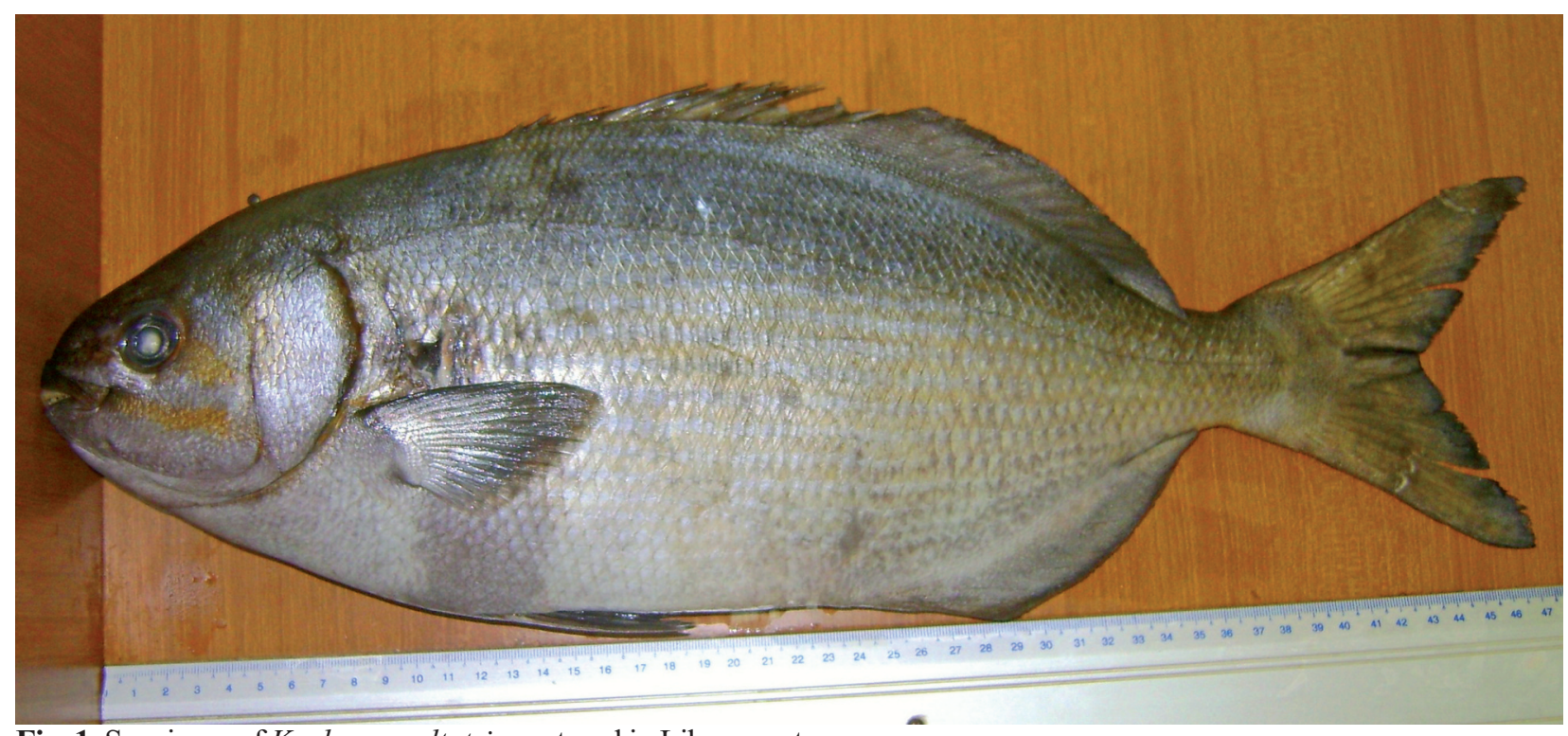

Fig. 1. Specimen of Kyphosus saltatrix captured in Libyan waters

\section{Table 1}

Morphological data for the specimen of Kyphosus saltatrix caught in Libyan waters

\begin{tabular}{|c|c|c|c|}
\hline Parameter & $\begin{array}{c}\text { Value } \\
{[\mathrm{g}]}\end{array}$ & $\begin{array}{l}\text { Value } \\
{[\mathrm{mm}]}\end{array}$ & $\begin{array}{c}\text { Relative value } \\
{[\% \text { of SL] }}\end{array}$ \\
\hline Total length (TL) & & 475 & - \\
\hline Fork length (FL) & & 431 & - \\
\hline Standard length (SL) & & 385 & 100 \\
\hline Head length (HL) & & 99 & 25.71 \\
\hline Head depth aeoOp & & 130 & 33.76 \\
\hline Head depth aeoOr & & 75 & 19.48 \\
\hline Head width aOp & & 60 & 15.58 \\
\hline Eye diameter & & 20 & 5.19 \\
\hline Pre-orbital length & & 30 & 7.79 \\
\hline Post-orbital length & & 52 & 13.50 \\
\hline Body width aDO & & 45 & 11.68 \\
\hline Body width aAO & & 35 & 9.09 \\
\hline Body height & & 160 & 41.55 \\
\hline Pre-dorsal length & & 155 & 40.25 \\
\hline Pre-anal length & & 245 & 63.63 \\
\hline Caudal peduncle length & & 70 & 18.18 \\
\hline Dorsal fin base length & & 200 & 51.94 \\
\hline Pectoral fin length & & 70 & 18.18 \\
\hline Pectoral fin base length & & 21 & 5.45 \\
\hline Pelvic fin length & & 57 & 14.80 \\
\hline Pelvic fin base length & & 16 & 4.15 \\
\hline Anal fin base length & & 89 & 23.11 \\
\hline Caudal fin height & & 155 & 40.25 \\
\hline Caudal fin length & & 95 & 24.63 \\
\hline Total weight & 1630 & & \\
\hline Gutted mass weight & 1400 & & \\
\hline
\end{tabular}

aeoOp $=$ at end of operculum, aeoOr $=$ at end of orbit, $\mathrm{aOp}=$ at operculum, $\mathrm{aDO}=$ at dorsal origin, $\mathrm{aAO}=$ at anal origin.
$K$. saltatrix is probably a species, tolerating a wide range of seawater temperatures (Canas et al. 2005).

Additionally, ports of big coastal cities are exposed to alien species as a consequence of shipping traffic (Farrapeira et al. 2007). Port of Benghazi receives hundreds of ships annually from other regions of Libya and from all over the world and it is possible that some fish are becoming unintentional "stowaways". One of the options for such "refugees" would be to travel between the fouling organisms covering the submerged parts of a ship. In such case the ship's hull would function as an artificial reef providing not only adequate shelter against predators but also supplying an important food source through colonizing benthic macroalgae. (Canas et al. 2005, Silvano and Güth et al. 2006, Farrapeira et al. 2007). The more likely and already confirmed option, however, for the displacement of marine organisms including fish would be travelling inside the ballast tanks of ships (Pearce 2013). The ballast

Table 2

Meristic data for the specimen

of Kyphosus saltatrix caught in Libyan waters

\begin{tabular}{lc}
\hline Meristic data & Counts \\
\hline Dorsal fin spines + rays & XI +12 \\
Anal fin spines + rays & III +11 \\
Pectoral fin rays & 18 \\
Pelvic fin rays & $\mathrm{I}+5$ \\
Caudal fin rays & 18 \\
Pored scales in lateral line & 60 \\
Scale rows above lateral line & 12 \\
Scale rows below lateral line & 22 \\
Gill rakers on 1st arch & $7+17$ \\
Incisor-like teeth on upper jaw & 40 \\
Incisor like teeth on lower jaw & 42 \\
\hline
\end{tabular}


waters decidedly represent a serious vector for introduction of new species, which could have potential effect on ecosystem, particularly if those species succeed in establishing self-sustaining populations (Dulčić et al. 2010). The capture of this Kyphosus saltatrix specimen in a location off Benghazi Coast could possibly also be associated with the high abundance of macroalgae, constituting an attractive food source for this species. However, the stomach of this specimen was completely filled by Sargassum spp. macroalgae that are largely increasing in the area of capture, in association with small crustaceans and molluscs. This observation is in agreement with Clements and Choat (1997), who report that kyphosids appear to be strict herbivores that can derive adequate nutrition from algae with low levels of easily assimilable energy.

\section{ACKNOWLEDGEMENTS}

The authors wish to thank two anonymous reviewers for providing useful suggestions to improve the manuscript.

\section{REFERENCES}

Canas A., Vasconcelos P., Lino P.G., Santos M.N. 2005. Northernmost record of Kyphosus sectator (Osteichthyes: Perciformes: Kyphosidae) in the north-eastern Atlantic. Journal of the Marine Biological Association of the United Kingdom 85 (6): 1535-1537. DOI: 10.1017/ S0025315405012750

Carpenter K.E. 2002. Kyphosidae, Sea chubs. Pp. 1684-1687. In: Carpenter K.E. (ed.) The living marine resources of the Western Central Atlantic. Vol. 3. Bony fishes part 2. FAO, Rome.

Clements K.D., Choat J.H. 1997. Comparison of herbivory in the closely-related marine fish genera Girella and Kyphosus. Marine Biology 127 (4): 579-586. DOI: 10.1007/ s002270050048

Desoutter M. 1973. Kyphosidae. Pp. 420-421. In: Hureau J.C., Monod T. (eds.) Check-list of the fishes of the north-eastern Atlantic and of the Mediterranean. Vol. 1. UNESCO, Paris.

Desoutter M. 1990. Kyphosidae. Pp. 831-833. In: Quero J.C., Hureau J.C., Karrer C., Post A., Saldanha L. (eds.) Checklist of the fishes of the eastern tropical Atlantic. Vol. 2. UNESCO, Paris.

Dulčić J., Pallaoro A., Dragičević B., Stagličić-Radica N. 2010. First record of dwarf flathead Elates ransonnetii (Platycephalidae) in the Adriatic Sea. Cybium 34 (2): 222-223.

Farrapeira C.M.R., de Melo A.V.O.M., Barbosa D.F., da Silva K.M.E. 2007. Ship hull fouling in the port of Recife, Pernambuco. Brazilian Journal of Oceanography 55 (3): 207-221. DOI: 10.1590/S1679-87592007000300005

Francour P., Mouine N. 2008. First record of Kyphosus sectator (Kyphosidae) along the French Mediterranean coast. Cybium 32 (3): 275-276.
Froese R., Pauly D. (eds.) 2013. FishBase. [version 04/2013] http://www.fishbase.org.

Golani D., Orsi-Relini L., Massuti E., Quignard J.P. 2002. CIEM atlas of exotic species in the Mediterranean. In: Briand F. (eds.). Fishes. Vol. 1. CIESM, Monaco.

Hattour A. 2006. Première observation de la calicagère blanche Kyphosus sectatrix (Linnaeus, 1758) sur les côtes tunisiennes. Bulletin de l'Institut National des Sciecneces et Technologies de Salammbô 33: 123-125.

Hemida F., Kanoun N., Golani D., Ben Souissi J., Guélorget O., Capapé C. 2004. Records of the Bermuda sea chub, Kyphosus sectator (Linnaeus, 1758) (Osteichthyes: Kyphosidae) from the coastal waters of Algeria (southern Mediterranean). Annales, Series Historia Naturalis 14 (1): 49-52.

Kiparissis S., Loukovitis D., Batargias C. 2012. First record of the Bermuda sea chub Kyphosus saltatrix (Pisces: Kyphosidae) in Greek waters. Marine Biodiversity Records 5 (e11): [5 pages]. DOI: 10.1017/S1755267211001199

Lelong P. 2012. A new record of Bermuda sea chub, Kyphosus saltatrix (Linnaeus, 1758), (Osteichthyes, Kyphosidae) from Galite Islands (Tunisia, southern Mediterranean). Marine Life 18 (1): 3-7.

Merella P., Massuti E., Deudero S. 1998. On the occurrence of Kyphosus sectator (Osteichthyes: Kyphosidae) in the western Mediterranean. Journal of the Marine Biological Association of the United Kingdom 78 (2): 687-690. DOI: 10.1017/S0025315400041771.

Nelson J.S. 2006. Fishes of the world, 4th edn. Wiley, NewYork.

Pearce F. 2013. Ships must kill off the beasties in the ballast water. New Scientist 216 (2910): 24-25.

Sgano T. 1978. Kyphosidae. In: Fischer W. (ed.) FAO species identification sheets for fishery purposes. Western Central Atlantic (Fishing Area 31). Vol. 3. FAO, Rome.

Sgano T. 1981. Kyphosidae. In: Fischer W. (ed.) FAO species identification sheets for fishery purposes. Eastern Central Atlantic (Fishing Areas 34, 47 in part). Vol. 2. FAO, Rome.

Silvano R.A.M., Güth A.Z. 2006. Diet and Feeding Behavior of Kyphosus spp. (Kyphosidae) in a Brazilian Subtropical Reef. Brazilian Archives of Biology and Technology 49 (4): 623-629. DOI: 10.1590/S1516-89132006000500012

Tortonese E. 1986. Kyphosidae. Pp. 912-913. In: Whitehead P.J.P., Bauchot M.-L., Hureau J.-C., Nielsen J., Tortonese E. (eds.) Fishes of the northeastern Atlantic and the Mediterranean. UNESCO, Paris.

Wheeler A. 1985. The world encyclopaedia of fishes. Macdonald, London.

Received: 31 May 2013

Accepted: 22 August 2013

Published electronically: 30 September 2013 